\title{
Differences between dental health service quality and utilization of Community Health Centres in the City of Padang based on indicators of utilisation effectiveness
}

\author{
Azri Darma*, Hidayati ${ }^{*}$ Fadil Oenzil ${ }^{* *}$ \\ *Department of Dental Public Health, Faculty of Dentistry Andalas University, Indonesia \\ **Postgraduate Biomedical Department, Faculty of Medicine, Andalas University, Indonesia
}

\begin{abstract}
Introduction: The high prevalence of oral disease have not been followed by the availability of oral healthcare, especially at the community-based level. This study was aimed to determine the differences between dental health service quality and utilisation of community health centres in the city of Padang based on indicators of utilisation effectiveness. Methods: A cross-sectional survey was conducted towards two Community Health Services (Puskesmas) as the samples selected using random sampling technique. One Community Health Service was representing a rarely visited Community Health Service with $\leq 9$ patients visit per day, and another Community Health Service was representing oppositely. As much as 131 respondents were included in this study, selected using the purposive sampling method. Dimensional satisfaction of service quality including tangibility, reliability, responsiveness, assurance, and empathy, were collected by interviewing the respondents based on a self-reported questionnaire. All data were analysed using the chi-square test. Results: The majority of respondents agreed that dimensional satisfaction such as tangibility, reliability, responsiveness, assurance, and empathy at both Community Health Services were at a good level. There was a significant relationship $(p<0.05)$ between several dimensional satisfaction of service quality variables (the wide and clean parking area; intense involvement of dentists on every oral examination; friendly service by the front-office; and empathetic affection of dentists towards the patient's complain) and the utilisation of oral health services. Conclusion: No service differences found from relationship analysis between dental health service quality and utilisation of community health centres in the city of Padang based on indicators of utilisation effectiveness.
\end{abstract}

Keywords: Service quality, dimensional satisfaction, oral health service, service utilisation, Community Health Centre

P-ISSN 1979-0201, e-ISSN 2549-6212 Available from:http://jurnal.unpad.ac.id/pjd/article/view/18330

DOI:10.24198/pjd.vol30no2.18330

Submission: Nov 11, 2017; Reviewed: Mar 22, 2018; Resubmit: May 28, 2018; Accepted: Jul 13, 2018; Publishing: Jul 31,2018

Corresponding author: Hidayati, Department of Dental Public Health, Faculty of Dentistry, Andalas University, Indonesia Jl.UnivAndalas Limau Manis, Pauh, Padang Sumatera Barat 25163.Phone:+6281261882473;Email: hidayati@dent.unand.ac.id 


\section{INTRODUCTION}

Every Indonesian citizen has the right to get safe, qualified, and affordable health services. The Indonesian Health Law No. 36 of 2009 included this right guaranteed by the government. This right must be fulfilled so that there will be an increase in the health status of the community, and the state will get investment in the development of productive human resources (HR) socially and economically. Efforts to maintain and improve community degrees can be carried out through various sectors, one of which is dental and oral health services. ${ }^{1}$

Indonesian Basic Health Research in 2013 showed that around $25.9 \%$ of Indonesia's population had dental and oral health problems, there were $31.1 \%$ who received care and treatment from dentists, and $68.9 \%$ did not take care. This shows that nationally, dental and oral health problems are still a national problem, where people still have high dental and oral problems and have not utilised dental health services. ${ }^{2}$

The Community Health Centre (Puskesmas) is the spearhead of the implementation of health services and is a comprehensive and integrated organisational unit that is closest to the community. Community Health Centre services include efforts to improve, prevent, cure and restore function in the field of dental health. The role and function of the health centre in health development in Indonesia are very strategic because the Community Health Centre has the role of organising health efforts to increase awareness, willingness and ability to live healthily for every resident to obtain optimal health degrees.

Nurmala conducted a study on 360 respondents in 2003, finding that only $10 \%$ had gone to health care facilities such as Community Health Centre and others went to other health care facilities and $90 \%$ of the respondents suffered from caries. ${ }^{3}$ The low utilisation of health services can be caused either by the lack of quality services such as the number and type of facilities and infrastructure available, limited personnel, availability of services and management of the Community Health Centre that have not been good. ${ }^{4}$

The quality of health services will tend to increase the use of health facilities. Improving the quality of services will lead to reciprocal effects on health service facilities, where if the quality of service is good, the health care facilities will get a good response, and vice versa. ${ }^{5,6}$

The description above shows that there are differences in the number of visits per health centre. The difference in service visits is due to differences in patient and community experience, service micro-systems, health service organisation systems and health service environments in each community health centre in Padang City. ${ }^{7}$ Problems with the quality of health services are important things to discuss to achieve quality services. The final orientation of service quality is excellent health services. Excellent health services as a form of service to patients who meet the needs and desires of patients so that patient satisfaction and patient trust increase. ${ }^{7}$

The quality of health services must be in accordance with proper professional standards by utilising resources reasonably, efficiently, effectively within the limited capacity of the government and society, as well as being held safely and satisfying customers according to proper norms and ethical quality of existing services. ${ }^{8}$ Service quality standards can be measured by referring to the dimensions of service quality which consists of five aspects, namely tangible, reliability, responsiveness, assurance, and empathy. ${ }^{9}$

Other factors that can affect the level of patient visits to the use of health care facilities are loyalty, medical skills, and the timeliness of health practitioners in health services. These three points are also included in the scope of the service quality standard dimensions. ${ }^{10,11}$

The quality of health services and the impact of the use of health care facilities leads to the need for research on differences in the quality of services with the use of dental health services in Community Health Centres in the City of Padang. This study was aimed to determine the differences between dental health service quality and utilisation of community health centres in the city of Padang based on indicators of utilisation effectiveness.

\section{METHODS}

This research was survey research with a crosssectional study design that has passed the ethical 
review by the Research Ethics Committee of the Faculty of Medicine Andalas University. The population in this study were all dental poly patients in the working area of the Health Office of the City of Padang consisting of 22 health centres with details of 10 health centres with average visits per day $\geq 9$ patients and 12 puskesmas with $<9$ patient visits per day.

Determination of the community health centre samples was carried out by purposive sampling method to determine the community health centre which became the study sample. Determination of the community health centre was based on the number of random patient visits. Determination of the two categories of community health centre was based on the provisions of the Ministry of Health of the Republic of Indonesia in 1995 stated that the effectiveness of utilisation of community health centre as if the average visit of dental patients is 9 people per day ${ }^{11}$ so that Rawang Community Health Centre was designated as a representative of community health centre with $<9$ people per day and Lubuk Begalung Health Center with patient visits of $\geq 9$ people per day.

Data retrieval research was conducted in October and November 2016. Calculation of the number of respondents was done by using Slovin Formula and found the number of respondents was 58 samples in Rawang Health Center and 73 samples in Lubuk Begalung Health Center, so the total number of samples became 131 samples. Respondents in this study must meet the criteria including aged 18-65 years old, patients who go to the dental polyclinic, new patients who have received services in the clinic and can communicate well.

Datacollection on the quality of dental health services was carried out using a questionnaire containing 28 questions that had been tested for validity and reliability (Cronbach's alpha = 0.54). The implementation of the questionnaire was done by digging information directly to the respondents by fulfilling the dental health service quality indicators consisting of dimensions of tangible, reliability, responsiveness, assurance, and empathy.

Furthermore, data on the number of patient visits to the Padang City Health Center dental clinic were obtained from the register data. Determination of the quality of dental health services is done using a Likert scale which is simplified into two levels namely agreeing and disagreeing. Data analysis using a computerised system, with univariate analysis used to determine the frequency distribution of respondents' characteristics data and the quality of health services, while bivariate analysis to analyse the relationship between service quality and use of dental health services in the Community Health Centre of the City of Padang using the chi-square test.

\section{RESULT}

Table 1 shows that the most age group in Rawang and Lubuk Begalung Community Health Centres is 46-71 years; the next age group is $26-45$ years; while the 18-25 year age group is the lowest group. The results showed that female respondents were more than male respondents. Based on the level of education in the two community health centre, the majority of respondents had high school education levels. Respondents with bachelor degree education were higher in the Lubuk Begalung Community Health Centre than the Rawang Community Health Centre. Whereas based on the respondent's occupation, most of the respondents were unemployed in the Rawang Community Health Centre or Lubuk Begalung Community Health Centre. Government employee groups tend to be higher in the Lubuk Begalung Community Health Centre than the Rawang Community Health Centre.

Table 2 shows that a large parking lot and a clean parking lot show significantly different perceptions of the two community health centres. In Rawang Community Health Centre, respondents' perceptions of the parking conditions were extensive which stated they did not agree for $56.89 \%$, while in Lubuk Begalung Community Health Centre only $28.77 \%$. Most respondents agreed to the perception of a clean parking lot, with details of $100 \%$ in Lubuk Begalung Community Health Centre and $93.11 \%$ in Rawang Community Health Centre. The Chi-square test results showed that the differences were significant between the two variables with the average visit of dental polyclinic patients ( $p$-value $<0.05$ ).

Respondents' perceptions regarding dental examination variables of patients always 
Table 1. Characteristics of respondents on the use of health services based on indicator of effectiveness of dental utilisation in community health centres in the city of padang

\begin{tabular}{|c|c|c|c|c|c|}
\hline \multirow{3}{*}{ No. } & \multirow{3}{*}{ Respondent's characteristics } & \multicolumn{4}{|c|}{ Number of respondents in Community Health Centres } \\
\hline & & \multicolumn{2}{|c|}{ Rawang (n = 58) } & \multicolumn{2}{|c|}{ Lubuk Begalung $(n=73)$} \\
\hline & & $\mathrm{n}$ & $\%$ & $\mathrm{n}$ & $\%$ \\
\hline \multirow[t]{4}{*}{1.} & Age & & & & \\
\hline & a. $18-25$ years old & 8 & 13.8 & 11 & 15.1 \\
\hline & b. 26-45 years old & 23 & 39.7 & 23 & 31.5 \\
\hline & c. 46-71 years old & 27 & 46.6 & 39 & 53.4 \\
\hline \multirow[t]{3}{*}{2.} & Gender & & & & \\
\hline & a. Male & 12 & 20.7 & 20 & 27.4 \\
\hline & b. Female & 46 & 79.3 & 53 & 72.6 \\
\hline \multirow[t]{5}{*}{3.} & Education & & & & \\
\hline & a. Elementary school & 7 & 12.1 & 4 & 5.5 \\
\hline & b. Junior school & 9 & 15.5 & 11 & 15.1 \\
\hline & c. High school & 35 & 60.3 & 34 & 46.6 \\
\hline & d. Bachelor degree & 7 & 12.1 & 24 & 32.9 \\
\hline \multirow[t]{7}{*}{4.} & Occupation & & & & \\
\hline & a. Student & 4 & 6.9 & 6 & 8.2 \\
\hline & b. Government employee & 8 & 13.8 & 16 & 21.9 \\
\hline & c. Private employee & 3 & 5.2 & 3 & 4.1 \\
\hline & d. Entrepreneur & 8 & 13.8 & 14 & 19.2 \\
\hline & e. Labourer & 1 & 1.7 & 1 & 1.4 \\
\hline & f. Unemployed & 34 & 58.6 & 33 & 45.2 \\
\hline
\end{tabular}

Table 2. Difference in dimensions of physical evidence on the use of health services based on indicator of effectiveness of dental utilisation in community health centres in the city of padang

\begin{tabular}{|c|c|c|c|c|c|c|c|c|c|c|}
\hline \multirow{3}{*}{ No. } & \multirow{3}{*}{ Physical evidence (Tangible) } & \multicolumn{4}{|c|}{$\begin{array}{c}\text { Rawang community health } \\
\text { centre }(n=58)\end{array}$} & \multicolumn{4}{|c|}{$\begin{array}{l}\text { Lubuk begalung community } \\
\text { health centre }(n=73)\end{array}$} & \multirow{3}{*}{ P-value } \\
\hline & & \multicolumn{2}{|c|}{ Disagree } & \multicolumn{2}{|c|}{ Agree } & \multicolumn{2}{|c|}{ Disagree } & \multicolumn{2}{|c|}{ Agree } & \\
\hline & & $\mathrm{n}$ & $\%$ & $\mathrm{n}$ & $\%$ & $\mathrm{n}$ & $\%$ & $\mathrm{n}$ & $\%$ & \\
\hline 1. & The building looks clean and fine & 2 & 3.45 & 56 & 96.55 & 4 & 5.48 & 69 & 94.52 & 0.717 \\
\hline 2. & $\begin{array}{l}\text { The parking lot is wide enough to } \\
\text { accommodate the patient's vehicle }\end{array}$ & 33 & 56.89 & 25 & 43.11 & 21 & 28.77 & 52 & 71.23 & $0.002^{*}$ \\
\hline 3. & The parking lot looks clean from garbage & 4 & 6.89 & 54 & 93.11 & 0 & 0.00 & 73 & 100 & $0.033^{*}$ \\
\hline 4. & The waiting room looks clean and neat & 2 & 3.45 & 56 & 96.55 & 0 & 0.00 & 73 & 100 & 0.263 \\
\hline 5. & $\begin{array}{l}\text { The dental polyclinic practice room looks } \\
\text { neat and clean }\end{array}$ & 1 & 1.72 & 57 & 98.28 & 3 & 4.11 & 70 & 95.9 & 0.410 \\
\hline 6. & $\begin{array}{l}\text { The availability of dental care equipment } \\
\text { is quite complete }\end{array}$ & 20 & 34.48 & 38 & 65.52 & 24 & 32.88 & 49 & 67. 12 & 0.856 \\
\hline 7. & $\begin{array}{l}\text { Hygiene of dental care is maintained } \\
\text { properly }\end{array}$ & 0 & 0.00 & 58 & 100 & 3 & 4.11 & 70 & 95.9 & 0.121 \\
\hline 8. & $\begin{array}{l}\text { The appearance of dentists and nurses } \\
\text { seemed clean and neat }\end{array}$ & 1 & 1.72 & 57 & 98.28 & 1 & 1.37 & 72 & 98.63 & 0.399 \\
\hline
\end{tabular}

performed by dentists seemed to be significantly different in both categories of community health centre (Table 2 ). The results showed that $12.07 \%$ of respondents in Rawang Community Health Centre stated they did not agree, while in Lubuk Begalung Community Health Centre only $2.74 \%$ said they did not agree. The chi-square test results showed that there were significant differences between 
Table 3. Difference in respondent's perception dimensions towards reliability dimensional In the use of health services based on indicator of effectiveness of dental utilisation in community health centres in the city of padang

\begin{tabular}{|c|c|c|c|c|c|c|c|c|c|c|}
\hline \multirow{3}{*}{ No. } & \multirow{3}{*}{ Reliability } & \multicolumn{4}{|c|}{$\begin{array}{l}\text { Rawang community health } \\
\text { centre }(n=58)\end{array}$} & \multicolumn{4}{|c|}{$\begin{array}{l}\text { Lubuk begalung community } \\
\text { health centre }(n=73)\end{array}$} & \multirow{3}{*}{ P-value } \\
\hline & & \multicolumn{2}{|c|}{ Disagree } & \multicolumn{2}{|c|}{ Agree } & \multicolumn{2}{|c|}{ Disagree } & \multicolumn{2}{|c|}{ Agree } & \\
\hline & & $\mathrm{n}$ & $\%$ & $\mathrm{n}$ & $\%$ & $\mathrm{n}$ & $\%$ & $\mathrm{n}$ & $\%$ & \\
\hline 1. & $\begin{array}{l}\text { The patient's teeth examination always } \\
\text { done by dentists }\end{array}$ & 7 & 12.07 & 51 & 87.93 & 2 & 2.74 & 71 & 97.26 & $0.001^{*}$ \\
\hline 2. & $\begin{array}{l}\text { Dentists examined the teeth thoroughly and } \\
\text { patiently }\end{array}$ & 3 & 5.17 & 55 & 94.83 & 5 & 6.85 & 68 & 93.15 & 0.549 \\
\hline 3. & Dentist's work is neat and satisfying & 5 & 8.62 & 53 & 91.38 & 6 & 8.22 & 67 & 91.78 & 0.995 \\
\hline 4. & $\begin{array}{l}\text { Nurse's performance when helping dentists } \\
\text { is good }\end{array}$ & 17 & 29.31 & 41 & 70.69 & 12 & 16.44 & 61 & 83.56 & 0.164 \\
\hline 5. & Dentists work in agile performance & 3 & 5.17 & 55 & 94.83 & 5 & 6.85 & 68 & 93.15 & 0.187 \\
\hline
\end{tabular}

Table 4. Differences in respondents' perceptions of responsiveness dimensions in the use of health services based on indicator of effectiveness of dental utilisation in community health centres in the city of padang

\begin{tabular}{|c|c|c|c|c|c|c|c|c|c|c|}
\hline \multirow{3}{*}{ No. } & \multirow{3}{*}{ Responsiveness } & \multicolumn{4}{|c|}{$\begin{array}{c}\text { Rawang community health } \\
\text { centre }(n=58)\end{array}$} & \multicolumn{4}{|c|}{$\begin{array}{l}\text { Lubuk begalung community } \\
\text { health centre }(n=73)\end{array}$} & \multirow{3}{*}{ P-value } \\
\hline & & \multicolumn{2}{|c|}{ Disagree } & \multicolumn{2}{|c|}{ Agree } & \multicolumn{2}{|c|}{ Disagree } & \multicolumn{2}{|c|}{ Agree } & \\
\hline & & $\mathrm{n}$ & $\%$ & $\mathrm{n}$ & $\%$ & $\mathrm{n}$ & $\%$ & $\mathrm{n}$ & $\%$ & \\
\hline \multirow[t]{2}{*}{1.} & $\begin{array}{l}\text { The nurse is responsive and agile at } \\
\text { serving patients }\end{array}$ & 9 & 15.52 & 49 & 84.48 & 11 & 15.07 & 62 & 84.93 & 0.531 \\
\hline & $\begin{array}{l}\text { The patient does not wait for long to get } \\
\text { the dentist's service when entering the } \\
\text { practice room }\end{array}$ & 3 & 5.17 & 55 & 94.83 & 8 & 10.96 & 65 & 89.04 & 0.460 \\
\hline 3. & The dentist asks the patient's complaints & 2 & 3.45 & 56 & 96.55 & 4 & 5.48 & 69 & 94.52 & 0.732 \\
\hline 4. & $\begin{array}{l}\text { The dentist respond well to patient } \\
\text { questions }\end{array}$ & 1 & 1.72 & 57 & 98.28 & 6 & 8.22 & 67 & 91.78 & 0.209 \\
\hline 5. & $\begin{array}{l}\text { The dentist handle patient complaints } \\
\text { responsively }\end{array}$ & 0 & 0.00 & 58 & 100 & 4 & 5.48 & 69 & 94.52 & 0.102 \\
\hline 6. & $\begin{array}{l}\text { The dentist provides information regarding } \\
\text { the services provided }\end{array}$ & 4 & 6.89 & 54 & 93.11 & 6 & 8.22 & 67 & 91.78 & 0.752 \\
\hline
\end{tabular}

the variables regarding the patient's dental examination always performed by the dentist and the average visit of the dental polyclinic patient $(p<0.05)$.

Table 4 illustrates that respondents' perceptions of the dimensions of responsiveness are relatively the same in both categories of community health centres and most respondents agree and strongly agree on average $>90 \%$ of the responsiveness of nurses and dentists. Chi-square test results indicated that there was no significant relationship between all responsiveness variables with the average visit of dental polyclinic patients $(p>0.05)$.

Table 5 shows that respondents' perceptions of the four variables from the assurance dimension are relatively the same in Rawang Community Health Centre and Lubuk Begalung Community Health Centre. Most respondents agree and strongly agree ( $>90 \%$ ) of the four variables. The results of this study indicated that most patients were satisfied with the quality of service from the assurance dimension in the two categories of the community health centre. The chi-square test results showed that there were no significant differences between the four assurance variables with the average visits of dental polyclinic patients $(p>0.05)$.

Table 6 describes that the respondents' perceptions of the locket officer variable gave service friendly and the doctor would listen to the patient's complaints, significantly different in the 
Table 5. Differences in respondent's dimensions on assurance in the use of health services based on indicator of effectiveness of dental utilisation in community health centres in the city of padang

\begin{tabular}{|c|c|c|c|c|c|c|c|c|c|c|}
\hline \multirow{3}{*}{ No. } & \multirow{3}{*}{ Assurance } & \multicolumn{4}{|c|}{$\begin{array}{c}\text { Rawang community health } \\
\text { centre }(n=58)\end{array}$} & \multicolumn{4}{|c|}{$\begin{array}{l}\text { Lubuk begalung community } \\
\text { health centre }(n=73)\end{array}$} & \multirow{3}{*}{ P-value } \\
\hline & & \multicolumn{2}{|c|}{ Disagree } & \multicolumn{2}{|c|}{ Agree } & \multicolumn{2}{|c|}{ Disagree } & \multicolumn{2}{|c|}{ Agree } & \\
\hline & & $n$ & $\%$ & $\mathrm{n}$ & $\%$ & $n$ & $\%$ & $\mathrm{n}$ & $\%$ & \\
\hline 1. & $\begin{array}{l}\text { The dentist ask for approval before taking } \\
\text { any medical decision on patients }\end{array}$ & 3 & 5.17 & 55 & 94.83 & 11 & 15.07 & 62 & 84.93 & 0.161 \\
\hline 2. & $\begin{array}{l}\text { The dentist provides comfort and safety } \\
\text { when examining patients }\end{array}$ & 3 & 5.17 & 55 & 94.83 & 3 & 4.11 & 70 & 95.89 & 0.956 \\
\hline 3. & $\begin{array}{l}\text { The dentist/nurse is careful in carrying out } \\
\text { their work }\end{array}$ & 0 & 0.0 & 58 & 100 & 2 & 2.74 & 71 & 97.26 & 0.436 \\
\hline 4. & $\begin{array}{l}\text { The treatment given is able to cure the } \\
\text { patient's complain }\end{array}$ & 2 & 3.45 & 56 & 96.55 & 7 & 9.59 & 65 & 90.41 & 0.222 \\
\hline
\end{tabular}

Table 6. Perbedaan dimensi persepsi responden terhadap dimensi empati pada penggunaan layanan kesehatan berdasarkan indikator efektivitas pemanfaatan gigi di puskesmas kota padang $(n=131)$

\begin{tabular}{|c|c|c|c|c|c|c|c|c|c|c|}
\hline \multirow{3}{*}{ No. } & \multirow{3}{*}{ Empathy } & \multicolumn{4}{|c|}{$\begin{array}{l}\text { Rawang community health } \\
\text { centre }(n=58)\end{array}$} & \multicolumn{4}{|c|}{$\begin{array}{l}\text { Lubuk begalung community } \\
\text { health Centre }(n=73)\end{array}$} & \multirow{3}{*}{ P-value } \\
\hline & & \multicolumn{2}{|c|}{ Disagree } & \multicolumn{2}{|c|}{ Agree } & \multicolumn{2}{|c|}{ Disagree } & \multicolumn{2}{|c|}{ Agree } & \\
\hline & & $\mathrm{n}$ & $\%$ & $\mathrm{n}$ & $\%$ & $\mathrm{n}$ & $\%$ & $\mathrm{n}$ & $\%$ & \\
\hline 1. & The counter clerk provides friendly service & 4 & 6.89 & 54 & 93.11 & 16 & 21.92 & 67 & 91.78 & $0.034^{*}$ \\
\hline 2. & The doctor is friendly and greets & 3 & 5.17 & 55 & 94.83 & 4 & 5.48 & 69 & 94.52 & 0.437 \\
\hline 3. & The nurse is polite and easy to smile & 6 & 10.34 & 52 & 89.66 & 8 & 10.96 & 65 & 89.04 & 0.240 \\
\hline 4. & Doctors want to listen to patient complaints & 2 & 3.45 & 56 & 96.55 & 0 & 0.0 & 73 & 100 & $0.042^{*}$ \\
\hline 5. & $\begin{array}{l}\text { Patients feel comfortable consulting with } \\
\text { the doctor }\end{array}$ & 0 & 0.0 & 58 & 100 & 6 & 8.22 & 67 & 91.78 & 0.064 \\
\hline
\end{tabular}

Keterangan: * $p<0.05$ Dan $n=131$

two categories of the community health centres. The results of the statistical analysis showed that the two variables had a significant difference with the average visit in the City of Padang City community healthcentres with thep-value of $<0.05$.

\section{DISCUSSION}

Characteristics of respondents covering aspects of age, gender, education and employment have some similarities and differences between Rawang Community Health Centre and Lubuk Begalung Community Health Centre. The age group that was dominant in the two categories of community health clinics was $46-71$ years; this indicated that the age group of elderly adults dominated the study sample. According to the Ministry of Health of the Republic of Indonesia in 2009, the age group 46-71 years was classified as the elderly. ${ }^{12}$ In this study, dental problems that were often found in the two community health centres were in the advanced adult age group. These results were following Septiani's study in 2014 which also showed that dental caries is one of the most common chronic conditions in the elderly. ${ }^{13}$

The percentage of female was more than that of men in both community health centre. This condition was related to the type of work that was also dominated by housewives who did not work compared to other types of work. The results of this study were also supported by the research of Dewi in 2009 which stated that in general patients who visit Yogyakarta community health centre were predominantly female. ${ }^{14}$

Education in the two community health centre categories showed a difference, in the most Rawang Community Health Centre were high school (60.3\%), and junior high school (15.5\%) education levels, while in the Lubuk Begalung Community Health Centre the highest was high school (46.6\%) and Bachelor (32.9\%). The difference in education was also related to the type of work; the results 
of the study showed that the government officer group is higher in Lubuk Begalung Community Health Centre than the Rawang Community Health Centre.

The quality of services in terms of the dimensions of physical evidence (tangibility), based on statistical tests, namely a parking space that was large enough to accommodate community health centre patient vehicles $(p=$ $0.002)$ and a clean parking lot $(p=0.033)$ has a significant relationship with use of dental health services at Rawang Community Health Centre and Lubuk Begalung Community Health Centre in the City of Padang. The results of this study also indicated that respondents' perceptions of the physical evidence aspects of the variable parking area which was quite large and clean parking lots have significant differences between the two categories of Community Health Centre. In the Rawang Community Health Centre, the patient's perception of the size of the parking lot was $56.89 \%$ of respondents who disagree, while the Lubuk Begalung Community Health Centre per day was only $28.77 \%$. As much as $6.89 \%$ of respondents did not agree that the Rawang Health Center had a clean parking lot, while all respondents $(100 \%)$ stated that the parking space at the Lubuk Begalung Community Health Center was clean of rubbish. Therefore, the dimensions of the tangible was based on the broad and neat categories of parking spaces in Lubuk Begalung Community Health Centre which was of better quality compared to Rawang Community Health Centre.

The results of this study indicated that the quality of the parking lot greatly affects the number of visits to dental polyclinic patients at the community health centre of the city of Padang. Good quality parking can increase the efficiency of health care use ( $\geq 9$ patients per day), whereas poor quality parking can cause low or nonstandard use of health services ( $<9$ patients per day). Direct observation also proves that the Lubuk Begalung Community Health Centre has a parking space that is wider and cleaner than the Rawang Community Health Centre (average visits $<9$ per day).

Cleanliness of the parking lot is a category of physical evidence that is very real and easily felt by visitors/patients. The results of this study were by the results of a study conducted by Mumu et al. in 2015 which stated that physical evidence was significantly related to patient satisfaction, including neat and clean yard conditions. ${ }^{15}$ The results of the study conducted by Saragih also showed that there was a significant relationship between physical evidence and patient visits at the Pekan Baru City Community Dental Centre. ${ }^{5}$ This means that the community health centre that does not meet the dimensions of satisfaction with physical evidence in polygamous patients will make the visit low and below the standard.

The results of the study illustrated that most aspects of the physical evidence of the community health centre in the city of Padang were standard in terms of the appearance of clean/beautiful public buildings, clean waiting rooms, clean practice rooms, hygiene of dental care tools, and the mien of doctors/dental nurses. The results of this study were also following the results of the study of Herlina et al. in 2016 regarding patient perceptions of the appearance of physical evidence (waiting room conditions, dental health examinations in the Banjarmasin City Community Health Centre showed that an average of $65 \%$ patients stated good quality. ${ }^{16}$

Based on the dimensions of reliability, the category of "dental examination always carried out by dentists" has a significant relationship to the use of dental health services in the Padang City Community Health Centres and had significant differences between the two community health centres. In Rawang Community Health Centre, dental examinations by nurses (not dentists) were still often carried out, whereas, in Lubuk Begalung Community Health Centre, dental examinations were almost always performed by dentists (the percentage of respondents agreeing to reach $97.26 \%$ ). Thus, the dimension of reliability has a more significant influence on patient satisfaction, following the statement of Irawan in 2008 which stated that most $( \pm 60 \%)$ consumers were not satisfied in receiving services due to complaints from reliability dimensions. ${ }^{17}$

The quality of service from the responsiveness dimension to the use of dental health services in the Padang City Community Health Centre based on the results of statistical analysis showed that there were no significant differences. The dimension of responsiveness is the willingness of doctors or nurses to help patients 
and provide fast service. Data on respondents' perceptions of the responsiveness variable were relatively similar in the two categories of the Community Health Centre. Most respondents (> $90 \%$ ) agreed on all responsiveness variables in the two categories of community health centres. This indicated that respondents' assessment of the dimensions of reliability in the two categories of community health centres was of good quality. According to Regulation of the Minister of Health of the Republic of Indonesia No. 129 of 2008 concerning minimum hospital service standards, one of the standards of outpatient care is customer satisfaction of more than $90 \% .{ }^{18}$ The results of the study conducted by Kambong et al. in 2013 showed that there was a relationship between nurse care in the dimensions of physical evidence, reliability, assurance and empathy with patient satisfaction, but there was no relationship between nurse care in the dimensions of responsiveness and patient satisfaction. ${ }^{19}$

The results of the research conducted by Saragih in 2009 showed that there was a relationship between responsiveness and visits at the Pekanbaru City Community Dental Centre. ${ }^{5}$ In this case, Azwar in 1996 had already stated that the patient's perception of the quality of health services is subjective, which is the result of an affection reaction (judgment of one's feelings). Subjective affective reactions can produce the same or different opinions, even though those judged are the same. The appearance of an affective reaction was determined by the background or characteristics of the individual. ${ }^{20}$ Thus there were differences in the results of this study with the research of Saragih, which was possibly related to differences in affective reaction of respondents in the City of Padang within the City of Pekanbaru which was also different. ${ }^{5}$ This difference may also be associated with the quality of services that are not necessarily precisely the same between Padang City Community Health Centres and Pekanbaru City Community Health Centres.

The Lubuk Begalung Community Health Centre has an average visit that was higher than the Rawang Community Health Centre due to its more strategic location. Factors in the work area were also likely to determine the number of patient visits. Lubuk Begalung Community
Health Centre (62,649 people) had more work area coverage than the coverage area of Rawang Community Health Centre (24,568 people). The results of the study of Herlina et al. in 2014 showed that the majority of patients stated that the location of the strategic community health centre position was reported as a good category by the opinions of respondents in the Banjarmasin City health facilities. ${ }^{16}$ The strategic position of the community health centre was beneficial for the community in terms of ease of transportation.

The results of statistical analysis based on the dimensions of assurance show that there were no significant differences between all assurance variables (4 variables) and the use of dental health services in the Community Health Centre of the City of Padang. Most respondents (> 90\%) agreed to all the responsiveness variables which indicated that in terms of assurance, dental health services in the City of Padang were of good quality.

Patients in the Lubuk Begalung Community Health Centre were more dissatisfied (15.11\%) with the performance of doctors asking for medical approval before taking action, than the Rawang Community Health Centre (5.2\%). This is probably due to the high visits of patients in Lubuk Begalung Community Health Centre so that sometimes they feel that the doctor must act quickly and should not ask for medical approval before taking action.

There was a significant difference between the relationship of service quality from the empathy dimension to the use of dental health services in the Community Health Centre of the City of Padang. Most of the respondents (> 90\%) stated that the locket officer at both Rawang and Lubuk Begalung Community Health Centres provided friendly service. However, there were still many patients who feel dissatisfied (disagree) with the locket officer to provide services in a friendly manner, which means that the services of the locket officer were considered less favourable. Many patients who were dissatisfied with the services of the locket officer in the Lubuk Begalung Community Health Centre, may be due to the higher number of patients visiting the locket officer who often ignore friendly attitude in serving patients or because of the lack of consistency in the attitude of hospitality in patient care.

Most of the respondents in Rawang Health Center (96.8\%) and all Lubuk Begalung Community 
Health Center respondents (100\%) stated that doctors were consistent in listening to complaints and patients were satisfied. Therefore, both community health centres have a good quality based on the dimensions of empathy. This is in accordance with a study conducted by Dewi in 2009 regarding patient satisfaction with patientdoctor communication in Yogyakarta Community Health Centre which showed that the highest level of satisfaction was in the dimension of empathy (64.1\% very satisfied and $32.8 \%$ satisfied). ${ }^{14}$

Service quality regarding the use of dental health services based on the effectiveness indicators of the utilisation of puskesmas in the City of Padang, which consists of five aspects, namely tangible, reliability, responsiveness, assurance, and empathy, showed no service differences. Physical (tangible) in the form of differences in perceptions of service users regarding the parking capacity and cleanliness of the parking lot; Reliability showed that there were differences in service users' perceptions of dental examination always performed by dentists; Empathy indicated differences in perceptions of service users regarding locket officers to provide friendly service.

\section{CONCLUSION}

No service differences found from relationship analysis between dental health service quality and utilisation of community health centres in the city of Padang based on indicators of utilisation effectiveness.

\section{REFERENCES}

1. The Republic of Indonesia Health Law No. 36 of 2009. Ministry of health of the republic of Indonesia. Jakarta; 2009.

2. National Institute of Health Research and Development (NIHRD). Indonesia Basic Health Research (RISKESDAS) 2012-2013. Jakarta: Ministry of Health of the Republic of Indonesia; 2013.

3. Nurmala ST. Profil penyakit periodontal penduduk di dua kecamatan kota Medan. Dentika Dent J. 2003;9(2):71-7.

4. Mulyadi D, Fadli UM, Ningsih FCK. Analisis Manajemen Mutu Pelayanan Kesehatan Pada
Rumah Sakit Islam Karawang. J Manajemen. 2013; 10(3): 1203-19.

5. Saragih S. Hubungan kualitas pelayanan dan kepuasan pasien dengan kunjungan di Balai Pengobatan Gigi Puskesmas Kota Pekanbaru [thesis]. Bandung: USU; 2009.

6. Machmud R. Manajemen mutu pelayanan kesehatan. J Kes Masy Andalas. 2008;2(2):18690. DOI: $10.24893 / \mathrm{jkma} .2 .2 .186-190.2008$

7. Ningrum RM, Huda $N$, Liestyaningrum $W$, Yuliastuti C. Hubungan mutu pelayanan kesehatan BPJS terhadap kepuasan pasien di Poliklinik THT Rumkital Dr. Ramelan Surabaya. STIKES Hangtuah Surabaya. 2014.

8. Parasuraman AP, Zeithaml VA, Berry LL. SERVQUAL: A multiple-item scale for measuring consumer perception of service quality. J Retail. 1988;64(1):12-40.

9. Dwiastuti SAP. Hubungan status kesehatan gigi dan mutu layanan dengan pemanfaatan balai pengobatan gigi puskesmas di Kabupaten Tabanan. J Kes Gi. 2013;1(1):10-5.

10. Puti WC. Pengaruh kualitas pelayanan dan kepuasan terhadap terhadap loyalitas pasien rawat jalan dan rawat inap Rumah Sakit Otorita Batam [minor thesis]. Bandung: Universitas Widyatama; 2013.

11. Directorate of Dental Health. Pedoman penyelengaraan upaya pelayanan kesehatan gigi di puskesmas. Jakarta: Ministry of Health of Republic of Indonesia; 1995.

12. Adisasmito W. National Health System [Presentation]. University of Indonesia. 2009.

13. Septiani Y, Novianti S. Hubungan tingkat keparahan karies gigi dengan kualitas hidup (terkait kesehatan gigi dan mulut) lansia di Desa Cimari Cikoneng Kabupaten Ciamis tahun 2014. Universitas Siliwangi. 2014.

14. Dewi A. Kepuasan pasien terhadap komunikasi dokter pasien di Puskesmas. Mutiara Medika. 2009;9(2):37-45.

15. Mumu LJ, Kandou GD, Doda DV. Analisis faktorfaktor yang berhubungan dengan kepuasan pasien di poliklinik penyakit dalam RSUP Prof. Dr. R.D. Kandou Manado. JIKMU. 2015;5(4):18.

16. Herlina N, Dewi N, Raharja SD. Gambaran dan Permintaan pasien terhadap fasyankes gigi di Puskesmas Kota Banjarmasin. Dentino J Ked Gi. 2016;1(1):75-82. 
17. Irawan H. 10 prinsip kepuasan pelanggan. Jakarta: Elex Media Komputindo; 2008.

18. The Republic of Indonesia Health Law No. 129 of 2008. Standar pelayanan minimal rumah sakit. Ministry of health of the republic of Indonesia. Jakarta; 2008.

19. Kambong M, Pangemanan JM, Kapantow GHM.
Hubungan antara pelayanan perawat dengan kepuasan pasien di Puskesmas Talawaan Kecamatan Talawaan, Kabupaten Minahasa Utara. Universitas Sam Ratulangi Manado. 2013.

20. Azwar A. Menjaga Mutu Pelayanan Kesehatan. Jakarta: Pustaka Sinar Harapan; 1996. 